\title{
MICROMECHANISM OF CU AND Fe ALLOYING PROCESS ON THE MARTENSITIC PHASE TRANSFORMATION OF NiTi-BASED ALLOYS: FIRST-PRINCIPLES CALCULATION
}

\author{
J.Y. Yin ${ }^{1}$, G.F. Li ${ }^{1,2}$, Y.L. Si ${ }^{1}$, G. Ying ${ }^{1}$, P. Peng ${ }^{2}$ \\ ${ }^{1}$ National Defence Key Discipline Laboratory of Light Alloy Processing Science and Technology, Nanchang \\ Hangkong University, Jiangxi, P. R. China \\ E-mail: lgf_918@126.com \\ ${ }^{2}$ School of Materials Science and Engineering, Hunan University, Hunan, P. R. China
}

Received July, 3, 2014

\begin{abstract}
Using first-principles pseudo-potential plane wave method, the formation enthalpy $\Delta H$, binding energy $\Delta E$, elastic constants, and electronic structure were calculated and analyzed carefully for NiTiX $(X=\mathrm{Cu}, \mathrm{Fe})$ shape memory alloy. The results show that the $\mathrm{Cu}$ or Fe element prefers to occupy the Ni site in the NiTi matrix phase respectively. Compared with the NiTi matrix phase, the $\Delta H, \Delta E, c_{44}$ and $c^{\prime}$ of $\mathrm{NiTi}(\mathrm{Cu})$ are similar to each other. However, the structural stability of the NiTi phase is improved obviously by the Fe alloying process. Simultaneously, the shear modulus $c_{44}$ and $c^{\prime}$ of NiTi (Fe) are larger than those of the NiTi matrix phase. Furthermore, Milliken population results indicate that $Q_{\mathrm{Cu}-\mathrm{Ti}}$ is smaller than $Q_{\mathrm{Ni}-\mathrm{Ti}}$ after the $\mathrm{Cu}$ alloying process, but $Q_{\mathrm{Fe}-\mathrm{Ti}}$ is larger than $Q_{\mathrm{Ni}-\mathrm{Ti}}$. The electron density difference shows that some covalent bonding exists between Fe and Ti elements. Based on the upward analysis, the difference in the phase stability and elastic constants of $\operatorname{NiTiX}(X=\mathrm{Cu}, \mathrm{Fe})$ is the substantial mechanism for the different $M_{\mathrm{s}}$ of $\operatorname{NiTiX}(\mathrm{X}=\mathrm{Cu}, \mathrm{Fe})$ although $\mathrm{Cu}$ or Fe substitutes for the same atom Ni elements in the NiTi matrix phase.
\end{abstract}

DOI: $10.15372 / \mathrm{JSC} 20150604$

K e y w o r d s: NiTi alloy, martensitic phase transformation, micromechanism, first principles calculation.

\section{INTRODUCTION}

Due to the remarkable shape memory effect (SME) and pseudoelasticity (PE), the TiNi-based shape memory alloys (SMAs) have attracted great researchers' attention [1]. Now two techniques exist to improve the mechanical performance of NiTi alloys: the first one is the thermomechanical manufacture, namely, the optimization of its microstructure; the second is the alloying process, namely, the changes in its components and phase structure. Sui et al. [2] found that after alloying the Co element, the recovery stress of $\mathrm{NiTiNb}(\mathrm{Co})$ was larger than that of NiTiNb SMA, albeit the phase hysteresis was shortened slightly. Saburi et al. [3] studied the effect of Co, Pd, and Fe elements on the phase transformation ability and found that the starting transformation temperature $M_{\mathrm{s}}$ of the NiTi martensitic phase was increased by Pd alloying but decreased by Co alloying albeit they substituted the same Ni atom. Xu et al. [4] investigated the relationship among the components, phase transformation temperature, and hysteresis of NiTiPd SMA. The results indicated that the phase transformation hysteresis would increase sharply when the atomic percent of the Pd element were more than

(C) Yin J.Y., Li G.F., Si Y.L., Ying G., Peng P., 2015 

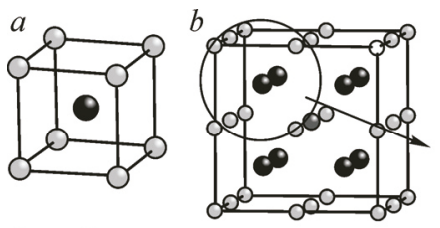

ONi OTi OX $=\mathrm{Fe}$ or $\mathrm{Cu}$

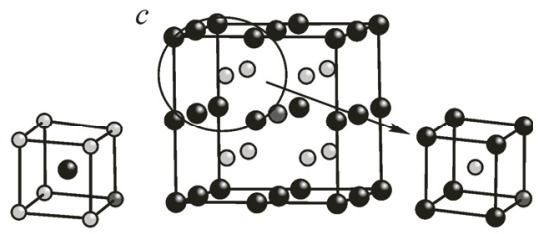

Fig. 1. Calculation models of $\mathrm{NiTi}(\mathrm{X})(\mathrm{X}=\mathrm{Cu}, \mathrm{Fe})$ phase $(a)$ NiTi model $(b)$ the model of $\mathrm{X} \rightarrow \mathrm{Ni}$ in $\mathrm{NiTi}(c)$ the model of Ti in NiTi

$33 \%$. It is reported that $\mathrm{Cu}[5]$ and $\mathrm{Fe}[6]$ elements similarly substituted for the Ni atom. However, $M_{\mathrm{s}}$ of NiTi was constant for $\mathrm{Cu}$ alloying but decreased by the Fe alloying process. Cai et al. [ 7 ] calculated the elastic constants and electronic structure of $\mathrm{B} 2$ ternary $\mathrm{Ti}_{50} \mathrm{Ni}_{43.75} \mathrm{Cu}_{6.25}$ and $\mathrm{Ti}_{50} \mathrm{Ni}_{43.75} \mathrm{Fe}_{6.25}$ shape memory alloys, and found that the Ti $d$ density of states (DOS) at the Fermi level was mainly responsible for the B2 phase stability of these alloys. But he did not show why $\mathrm{Cu}$ and Fe elements substituted for the same Ni element in NiTi SMA and the mechanism of this puzzle was not explored at all. Based on this confusion, this paper scrutinizes the different micromechanism of alloying processes for SMA by the first-principles calculation.

\section{CALCULATION MODEL AND METHOD}

The NiTi unit cell is a B2 crystal structure [ 8 ]. And its B19' structure is constructed according to the research of Ye et al. [ 8 ] and Gong et al. [9], as shown in Figs. 1 and 2. In order to eliminate the mutual effect between $\mathrm{Cu}-\mathrm{Cu}$ and $\mathrm{Fe}-\mathrm{Fe}$, in this paper we constructed a $2 \times 2 \times 2$ super cell model. All of these point defect models were relaxed as the following process: a first-principles pseudopotential plane-wave method, based on density functional theory, was used in this work [10]. Ultrasoft pseudopotentials in the reciprocal space with the exchange-correlation energy represented by the generalized gradient approximate (GGA) [ 11] and improved by Cepeley-Alder [12] were adopted for all elements in our models. In our simulation process, the cut-off energy of atomic wave functions

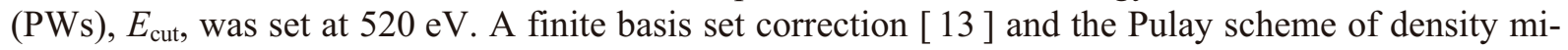
xing [14] were applied to evaluate the energy and stress. All atomic positions in the supercell with and without $\mathrm{Nb}$-doping were relaxed according to the total energy and force using the BFGS scheme [15], based on the cell optimization criterion (RMS force of $0.01 \mathrm{eV} / \AA$, stress of $0.5 \mathrm{GPa}$, and displacement of $0.005 \AA$ ). The calculation of the total energy and electronic structure was followed by cell optimization with SCF tolerance of $5.0 \times 10^{-5} \mathrm{eV}$ under the GGA Cepeley-Alder potential [12]. Sampling of the irreducible wedge of the Brillouin zone was performed with a regular MonkhorstPack grid of special $k$-points, which is $15 \times 15 \times 15$. All of the models were used in spin-polarized calculations to obtain the total energies.

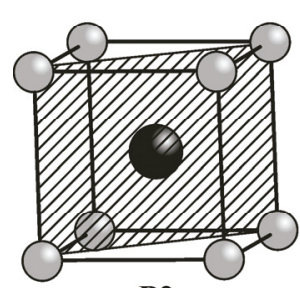

B2

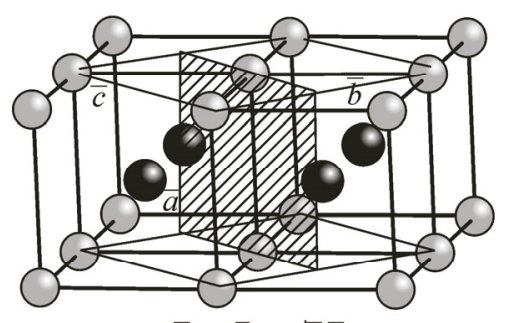

$|\bar{b}|=|\bar{c}|=\sqrt{2}|\bar{a}|$

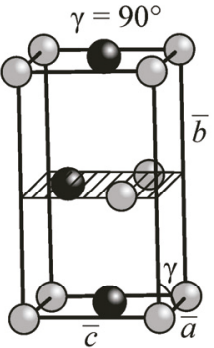

B19

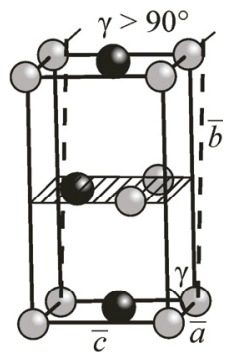

B19'

Fig. 2. Sketch map of the B2, B19 and B19' unit cells [ 8 ] 
$\mathrm{T}$ a b 1 e 1

Lattice Constant, Bulk Modulus, and Elastic Constants of the NiTi Crystal

\begin{tabular}{c|c|c|c|c}
\hline Parameter & This work & Exp. [16] & Tan et al. [ 17] & Borgia et al. [18] \\
\hline$a, \AA$ & 3.033 & 3.018 & 3.015 & 2.998 \\
$B, \mathrm{GPa}$ & 142.26 & - & - & - \\
$c_{11}$ & 162.57 & 162 & 179 & - \\
$c_{12}$ & 132.04 & 132 & 137 & - \\
$c_{44}$ & 46.83 & 36 & 40 & -
\end{tabular}

\section{RESULTS AND DISCUSSION}

Test of the potential function. In these tests, the crystal lattice $(a)$, bulk modulus $(B)$, and elastic constants $\left(c_{11}, c_{12}, c_{44}\right)$ of the NiTi crystal were calculated and set out in Table 1. Compared with previous experiments [16] and calculations [17,18], the results exhibite that calculated $c_{11}$ and $c_{12}$ of the NiTi matrix phase are consistent with the experiment [16]. Calculated $c_{44}(46.83 \mathrm{GPa})$ in this work is slightly larger than the experimental value $\left(c_{44}=36 \mathrm{GPa}\right)$, but it is close to that reported by Tan et al. $\left(c_{44}=40 \mathrm{GPa}\right)[17]$. This indicates that the calculation sets and method used are appropriate for investigating the microcosmic properties of NiTi alloy.

Stability of the $\mathbf{B} 2$ austenitic phase. As is well known, the binding energy $\Delta E$ represents the work of a crystal decomposition into atoms, which can be used to denote the crystal stability. The formation enthalpy $\Delta H$ refers to the energy of a compound composed of several single crystals. Therefore, the smaller the $\Delta H$, the more easily the compound is composed. Herein, $\Delta H$ and $\Delta E$ of NiTi (X) $(\mathrm{X}=\mathrm{Cu}, \mathrm{Fe})$ were calculated by the following equations [19]:

$$
\begin{gathered}
\Delta E=\frac{\left[E_{\mathrm{tot}}-l E_{\mathrm{Ni}}^{\mathrm{gas}}-m E_{\mathrm{Ti}}^{\mathrm{gas}}-n E_{\mathrm{X}}^{\mathrm{gas}}\right]}{l+m+n}, \\
\Delta H=\frac{\left[E_{\mathrm{tot}}-l E_{\mathrm{Ni}}-m E_{\mathrm{Ti}}-n E_{\mathrm{X}}\right]}{l+m+n},
\end{gathered}
$$

where $E_{\text {tot }}$ is the total energy of the NiTi (X) crystal and $l, m$, and $n$ represent the number of Ni, Ti, and $\mathrm{X}$ atoms in the $\mathrm{Ni}_{l-n} \mathrm{Ti}_{m}\left(\mathrm{X}_{n}\right)$ crystal respectively. $E_{\mathrm{Ni}}, E_{\mathrm{Ti}}$, and $E_{\mathrm{X}}$ are the energies of $f c c-\mathrm{Ni}, h c p-\mathrm{Ti}$, and other alloying elements; $E_{\mathrm{Ni}}=-1354.105 \mathrm{eV}, \quad E_{\mathrm{Ti}}=-1602.707 \mathrm{eV}, \quad E_{\mathrm{Cu}}=-1345.865 \mathrm{eV}, E_{\mathrm{Fe}}=$ $=-864.112 \mathrm{eV} . E_{\mathrm{Ni}}^{\mathrm{gas}}, E_{\mathrm{Ti}}^{\mathrm{gas}}$, and $E_{\mathrm{X}}^{\mathrm{gas}}$ are the energies of gaseous $\mathrm{Ni}, \mathrm{Ti}, \mathrm{Cu}$, and $\mathrm{Fe}$ atoms. In order to get the reliable energy of a gaseous atom, we constructed a $10 \times 10 \times 10 \AA^{3}$ vacuum box and put a single atom, such as $\mathrm{Ni}, \mathrm{Ti}, \mathrm{Cu}$, and $\mathrm{Fe}$, in the centre of the box to eliminate the atomic mutual effect. The results were $E_{\mathrm{Ni}}^{\mathrm{gas}}=-1350.405 \mathrm{eV}, E_{\mathrm{Ti}}^{\mathrm{gas}}=-1597.580 \mathrm{eV}, E_{\mathrm{Cu}}^{\mathrm{gas}}=-1343.933 \mathrm{eV}, E_{\mathrm{Fe}}^{\mathrm{gas}}=-856.383 \mathrm{eV}$ respectively (Table 2).

\section{Table 2}

Total Energy $E_{\mathrm{tot}}$, Binding Energy $\Delta E$, and Formation Enthalpy $\Delta H$ of $\operatorname{NiTiX}(\mathrm{X}=\mathrm{Cu}$ and $\mathrm{Fe})$ Alloys

\begin{tabular}{c|c|c|c}
\hline Calculation model & $E_{\text {tot }}, \mathrm{eV}$ & $\Delta E, \mathrm{eV} /$ atom & $\Delta H, \mathrm{eV} /$ atom \\
\hline B2-NiTi matrix phase & -23663.899 & -5.001 & -0.588 \\
NiTi $(\mathrm{Cu} \rightarrow \mathrm{Ni})$ & -23656.434 & -4.939 & -0.636 \\
NiTi $(\mathrm{Cu} \rightarrow \mathrm{Ti})$ & -23408.637 & -4.901 & -0.686 \\
NiTi $(\mathrm{Fe} \rightarrow \mathrm{Ni})$ & -23174.894 & -5.314 & -0.649 \\
NiTi $(\mathrm{Fe} \rightarrow \mathrm{Ti})$ & -22926.230 & -5.221 & -0.645
\end{tabular}


Table 2 shows that the binding energy $\Delta E(-4.939 \mathrm{eV} /$ atom $)$ of $\mathrm{B} 2-\mathrm{NiTi}(\mathrm{Cu} \rightarrow \mathrm{Ni})$ is smaller than that $(-4.901 \mathrm{eV} /$ atom $)$ of $\mathrm{B} 2-\mathrm{NiTi}(\mathrm{Cu} \rightarrow \mathrm{Ti})$, but the formation enthalpy $\Delta H(-0.636 \mathrm{eV} /$ atom $)$ of B2-NiTi $(\mathrm{Cu} \rightarrow \mathrm{Ni})$ is slightly larger than that $(-0.686 \mathrm{eV} /$ atom $)$ of $\mathrm{B} 2-\mathrm{NiTi}(\mathrm{Cu} \rightarrow \mathrm{Ti})$. Thus, the $\mathrm{B} 2-\mathrm{NiTi}(\mathrm{Cu} \rightarrow \mathrm{Ni})$ phase is more stable than the $\mathrm{B} 2-\mathrm{NiTi}(\mathrm{Cu} \rightarrow \mathrm{Ti})$ phase, which means that $\mathrm{Cu}$ elements prefer to substitute for the Ni atom in NiTi SMA [6].

As for the Fe alloying process, $\Delta E$ and $\Delta H$ of $\mathrm{B} 2-\mathrm{NiTi}(\mathrm{Fe} \rightarrow \mathrm{Ni})$ are both lower than those of B2-NiTi $(\mathrm{Fe} \rightarrow \mathrm{Ti})$, for example, $\Delta E_{\mathrm{Fe} \rightarrow \mathrm{Ni}}$ and $\Delta H_{\mathrm{Fe} \rightarrow \mathrm{Ni}}$ are $-5.314 \mathrm{eV} /$ atom and $-0.649 \mathrm{eV} /$ atom respectively, which are smaller than $\Delta E_{\mathrm{Fe} \rightarrow \mathrm{Ti}}(-5.221 \mathrm{eV} /$ atom $)$ and $\Delta H_{\mathrm{Fe} \rightarrow \mathrm{Ti}}(-0.645 \mathrm{eV} /$ atom $)$. Thus, the Fe element can substitute only for the Ni atom, which is consistent with the experiments [ 7 ].

Compared with the binding energy $(-5.001 \mathrm{eV} /$ atom $)$ and the formation enthalpy $(-0.588 \mathrm{eV} /$ atom $)$ of the original matrix phase $\mathrm{NiTi}, \Delta E_{\mathrm{Cu} \rightarrow \mathrm{Ni}}$ of $\mathrm{NiTi}(\mathrm{Cu})$ is slightly increased $(-4.939 \mathrm{eV} /$ atom) and $\Delta H_{\mathrm{Cu} \rightarrow \mathrm{Ni}}$ is slightly decreased $(-0.636 \mathrm{eV} /$ atom $)$. In contrast, the binding energy $(-5.314 \mathrm{eV} /$ atom $)$ and the formation enthalpy $(-0.649 \mathrm{eV} /$ atom $)$ of $\mathrm{B} 2-\mathrm{NiTi}(\mathrm{Fe} \rightarrow \mathrm{Ni})$ are both smaller than those of B2-NiTi. Then we draw the conclusion that the $\mathrm{Cu}$ alloying process obviously cannot enhance the structural stability of the NiTi matrix phase. However, the Fe element can substantially improve the structural stability of the NiTi matrix phase by the alloying process.

Stability of the B19' martensitic phase. It is reported that the phase transformation ability has a relationship with the stability of the austenitic B2 structure and the B19' martensitic structure. In this study we calculated the binding energy and the formation enthalpy of $\mathrm{B}^{\prime} 9^{\prime}-\mathrm{NiTi}(\mathrm{X} \rightarrow \mathrm{Ni})(\mathrm{X}=\mathrm{Cu}$, $\mathrm{Fe})$, as shown in Fig. 2. After the geometry relaxation, $\Delta E$ and $\Delta H$ of $\mathrm{B}^{\prime} 9^{\prime}-\mathrm{NiTi}, \mathrm{B} 19^{\prime}-\mathrm{NiTi}(\mathrm{Cu})$ and B19'-NiTi (Fe) were calculated by formulas (1) and (2), as shown in Table 3. From Table 3 it is seen that the binding energy and the formation enthalpy $(\Delta E=-5.186 \mathrm{eV} / \mathrm{atom}$ and $\Delta H=$ $=-0.773 \mathrm{eV} /$ atom $)$ of $\mathrm{B} 19^{\prime}-\mathrm{NiTi}$ are smaller than those $(\Delta E=-5.001 \mathrm{eV} /$ atom and $\Delta H=$ $=-0.558 \mathrm{eV} /$ atom $)$ of B2 $-\mathrm{NiTi}$ respectively, which means that the phase transformation $\mathrm{B} 2 \rightarrow \mathrm{B} 19^{\prime}$ can occur with a decrease in the temperature.

The results of the analysis of the effect of $\mathrm{Cu}$ alloying show that $\Delta E(-5.110 \mathrm{eV} / \mathrm{atom})$ and $\Delta H$ $(-0.752 \mathrm{eV} /$ atom $)$ of $\mathrm{B} 19^{\prime}-\mathrm{NiTi}(\mathrm{Cu} \rightarrow \mathrm{Ni})$ are smaller than those $(\Delta E=-4.939 \mathrm{eV} /$ atom and $\Delta H=$ $=-0.636 \mathrm{eV} /$ atom $)$ of $\mathrm{B} 2-\mathrm{NiTi}(\mathrm{Cu} \rightarrow \mathrm{Ni})$, but they are larger than those $(\Delta E=-5.186 \mathrm{eV} /$ atom and $\Delta H=-0.773 \mathrm{eV} /$ atom) of the $\mathrm{B} 19^{\prime}-\mathrm{NiTi}$ matrix phase, which indicates that the structural stability of $\mathrm{B} 19^{\prime}-\mathrm{NiTi}(\mathrm{Cu})$ is lower than that of B19'-NiTi.

As for the $\mathrm{Fe}$ alloying process, Table 3 shows that $\Delta E_{\mathrm{B} 19^{\prime}-\mathrm{NiTi}(\mathrm{Fe})}=-5.325 \mathrm{eV} /$ atom and $\Delta H_{\mathrm{B} 19^{\prime}-\mathrm{NiTi}(\mathrm{Fe})}=-0.786 \mathrm{eV} /$ atom of $\mathrm{B} 19^{\prime}-\mathrm{NiTi}(\mathrm{Fe} \rightarrow \mathrm{Ni})$ are smaller than those of $\mathrm{B} 2-\mathrm{NiTi}$ $(\mathrm{Fe} \rightarrow \mathrm{Ni})(\Delta E=-5.314 \mathrm{eV} /$ atom and $\Delta H=-0.649 \mathrm{eV} /$ atom $)$, and also smaller than those of original B19' - NiTi, namely the phase stability is improved by the Fe alloying process for NiTi SMA.

As for the $\beta$-style alloy, the more stable the $\beta$ phase, the much smaller the $M_{\mathrm{s}}$ is [8]. As compared with the binding energy of B2 and B19'-NiTi, NiTi $(\mathrm{Cu})$ and the NiTi (Fe) phase, it can be conjectured that $M_{\mathrm{s}}$ of $\mathrm{NiTi}(\mathrm{Cu})$ is similar to that of NiTi because of the little difference in the phase stability between them. Nevertheless, $M_{\mathrm{s}}$ of NiTi (Fe) decreases sharply as the stability of NiTi (Fe) is ameliorated by a Fe impurity. Otherwise, the energy difference between B2 and B19' can also provide some evidences about the effect of $\mathrm{Cu}$ or Fe alloying. A small difference in the binding energies of the

T a b l e 3

Total Energy $E_{\mathrm{tot}}$, Binding Energy $\Delta E$, and Formation Enthalpy $\Delta H$ of $\mathrm{B} 19^{\prime}-\mathrm{NiTi}(\mathrm{X}=\mathrm{Cu}, \mathrm{Fe})$

\begin{tabular}{c|c|c|c|c}
\hline Alloying model & Phase & $E_{\text {tol }}, \mathrm{eV}$ & $\Delta E, \mathrm{eV} /$ atom & $\Delta H, \mathrm{eV} /$ atom \\
\hline $\mathrm{NiTi}$ & $\mathrm{B} 19^{\prime}$ & -47333.7316 & -5.186 & -0.773 \\
$\mathrm{NiTi}(\mathrm{Cu})$ & $\mathrm{B} 19^{\prime}-\mathrm{NiTi}(\mathrm{Cu} \rightarrow \mathrm{Ni})$ & -47324.8234 & -5.110 & -0.752 \\
$\mathrm{NiTi}(\mathrm{Fe})$ & $\mathrm{B} 19^{\prime}-\mathrm{NiTi}(\mathrm{Fe} \rightarrow \mathrm{Ni})$ & -46844.1431 & -5.325 & -0.786
\end{tabular}


Elastic Constants of the $\mathrm{NiTiX}(\mathrm{X}=\mathrm{Cu}$ or $\mathrm{Fe})$ Alloy

\begin{tabular}{c|c|c|c||c|c|c|c}
\hline \multirow{2}{*}{$\begin{array}{c}\text { Elastic } \\
\text { constant, GPa }\end{array}$} & \multicolumn{3}{|c||}{ Model } & \multirow{2}{*}{$\begin{array}{c}\text { Elastic } \\
\text { constant, GPa }\end{array}$} & \multicolumn{3}{c}{ Model } \\
\cline { 7 - 9 } & NiTi & NiTi(Cu) & NiTi(Fe) & & NiTi & NiTi(Cu) & NiTi(Fe) \\
\hline \multirow{2}{*}{$c_{11}$} & 162.57 & 158.18 & 173.95 & $c_{44}$ & 46.83 & 45.69 & 51.54 \\
$c_{12}$ & 132.04 & 123.66 & 133.89 & $c^{\prime}$ & 15.27 & 17.26 & 20.03
\end{tabular}

austensite and martensite phases indicates that the B2 structure is stable in the low-temperature phase and thus leads to a lower $M_{\mathrm{s}}$ temperature [ 8 ]. Obviously the binding energy difference $\left(\Delta E_{\mathrm{B} 19^{\prime}}-\Delta E_{\mathrm{B} 2}\right)$ for the NiTi matrix phase is only $-0.185 \mathrm{eV}$, which is close to that $(-0.171 \mathrm{eV})$ of $\mathrm{NiTi}(\mathrm{Cu})$, but it is also much smaller than that $(-0.011 \mathrm{eV})$ of the $\mathrm{NiTi}(\mathrm{Fe})$ phase. Thus, $M_{\mathrm{s}}$ of $\mathrm{NiTi}(\mathrm{Fe})$ are smaller than those of NiTi and NiTi $(\mathrm{Cu}) \mathrm{SMA}$, which is consistent with the experiments.

Elastic constants. As for near-equiatomic NiTi alloys, Brill et al. [20 ] found its shear constant $c^{\prime}$ $\left(c^{\prime}=\left(c_{12}-c_{44}\right) / 2\right)$ softened and Otsuka et al. [21] found its $c_{44}$ decreased near its $M_{\mathrm{s}}$. Considering such an abnormal phenomenon, Planes et al. [22 ] ascribed the unstability of the NiTi alloy to a low shear modulus $c^{\prime}$. Zener et al. [23] believed that the stability of the $\beta$-Ti alloy could be determined by $c^{\prime}$ somewhere, meaning that the smaller the $c^{\prime}$ the more unstable the $\beta$-Ti alloy is. Thereinto $c_{44}$ and $c^{\prime}$ represent the shear deformation ability of a body centered cubic (bcc) structure along $\{100\}\langle 100\rangle$ and $\{110\}\langle 110\rangle$ directions respectively. The smaller $c_{44}$ or $c^{\prime}$ for the $\beta$-Ti alloy, the higher its shear transformation ability is, which means that $M_{\mathrm{s}}$ must be much more larger. On the contrary, $M_{\mathrm{s}}$ is smaller.

From crystal morphology, the B2 configuration is transformed into B19' by shear transmogrification along the $c_{44}$ or $c^{\prime}$ direction for NiTi SMA. If the shear transmogrification of NiTi (X) is more difficult, which means that there exist much more energy barriers in the phase transformation, then $M_{\mathrm{s}}$ of NiTi $(\mathrm{X})$ will be lower after the $\mathrm{X}(\mathrm{X}=\mathrm{Fe}$ or $\mathrm{Cu})$ alloying process $[6,7]$. On the contrary, $M_{\mathrm{s}}$ will be constant or somehow increased. In order to illuminate the effect of $\mathrm{Cu}$ or $\mathrm{Fe}$ alloying on the shear elastic constants of the NiTi alloy, in this work we calculated $c_{11}, c_{12}, c_{44}$, and $c^{\prime}$, as shown in Tables 1 and 4.

Considering the effect of $\mathrm{Cu}$ alloying in NiTi SMA, it is found that $c_{44}(45.69 \mathrm{GPa})$ of NiTi $(\mathrm{Cu})$ is equivalent to that $(46.83 \mathrm{GPa})$ of the NiTi matrix phase, although $c^{\prime}(17.26 \mathrm{GPa})$ of $\mathrm{NiTi}(\mathrm{Cu})$ is slightly larger than that $(15.27 \mathrm{GPa})$ of NiTi. However, after Fe alloying process, $c_{44}\left(c_{44}=46.83 \mathrm{GPa}\right)$ and $c^{\prime}\left(c^{\prime}=15.27 \mathrm{GPa}\right)$ of the NiTi matrix phase increase to $51.54 \mathrm{GPa}$ and $20.03 \mathrm{GPa}$ for the NiTi $(\mathrm{Fe})$ phase respectively. Then we can indicate that after the $\mathrm{Cu}$ alloy process, because of a smaller change in $\Delta c_{44}\left(c_{44-\mathrm{NiTi}(\mathrm{Cu})}-c_{44-\mathrm{NiTi}}=1.14 \mathrm{GPa}\right)$ and $\Delta c^{\prime}\left(c_{-\mathrm{NiTi}(\mathrm{Cu})}^{\prime}-c_{-\mathrm{NiTi}}^{\prime}=1.99 \mathrm{GPa}\right)$, the shear transmogrification ability of $\mathrm{B} 2 \rightarrow \mathrm{B} 19^{\prime}$ for the NiTi $(\mathrm{Cu})$ phase is equal to that of the NiTi matrix phase. As for $\mathrm{Fe}$ alloying process, $\Delta c_{44}\left(c_{44-\mathrm{NiTi}(\mathrm{Fe})}-c_{44-\mathrm{NiTi}}=4.71 \mathrm{GPa}\right)$ and $\Delta c^{\prime}\left(c_{-\mathrm{NiTi}(\mathrm{Fe})}^{\prime}-\right.$ $\left.-c_{-\mathrm{NiTi}}^{\prime}=4.96 \mathrm{GPa}\right)$ increase drastically as compared with the NiTi matrix phase, which means that the energy barrier in the $\mathrm{B} 2 \rightarrow \mathrm{B} 19^{\prime}$ phase transformation process of the $\mathrm{NiTi}(\mathrm{Fe})$ phase is sharply increased. Then we can conclude that although $\mathrm{Cu}$ and $\mathrm{Fe}$ substitute for the same Ni atom in the NiTi matrix phase, the different effect on the shear constants $c_{44}$ and $c^{\prime}$ results in their different effect on $M_{\mathrm{s}}$.

Evolution of the bonding strength. In order to study the substential electronic interaction in the NiTi $(\mathrm{X})(\mathrm{X}=\mathrm{Cu}$ or Fe) alloy, the overlap charge population and Mulliken charge between $\mathrm{X}$ and its nearest-neighbor atoms were calculated in this paper. According to Mulliken's population theory, the Mulliken charge $Q(\mathrm{~A})$ of A atom and the bond overlap population $Q_{\mathrm{A}-\mathrm{B}}$ between $\mathrm{A}$ and $\mathrm{B}$ atoms were defined as follows [24]:

$$
Q_{\mathrm{AB}}=\sum_{k} w_{k} \sum_{\mu}^{\mathrm{A}} \sum_{v}^{\mathrm{A}} 2 P_{\mu \nu}(k) S_{\mu \nu}(k),
$$


Average Mulliken Population $\bar{Q}_{\mathrm{A}-\mathrm{B}}$ and Mulliken Charge $\bar{Q}(\mathrm{~A})$ of the

\begin{tabular}{l|c|c|c|c|c|c}
\multicolumn{7}{c}{ B2-NiTi(X) $(\mathrm{X}=\mathrm{Cu}, \mathrm{Fe})$ Phase } \\
\hline \multicolumn{1}{c|}{ Model } & Phases & $\bar{Q}_{\mathrm{X}-\mathrm{Ti}}$ & $\bar{Q}_{\mathrm{Ni}-\mathrm{Ti}}$ & $Q(\mathrm{X})$ & $\bar{Q}(\mathrm{Ti})$ & $\bar{Q}(\mathrm{Ni})$ \\
\hline NiTi & $\mathrm{B} 2$ & - & 0.22 & - & 0.29 & -0.29 \\
$\mathrm{NiTi}(\mathrm{Cu})$ & $\mathrm{B} 2-\mathrm{NiTi}(\mathrm{Cu} \rightarrow \mathrm{Ni})$ & 0.06 & 0.21 & 0.12 & 0.13 & -0.17 \\
$\mathrm{NiTi}(\mathrm{Fe})$ & $\mathrm{B} 2-\mathrm{NiTi}(\mathrm{Fe} \rightarrow \mathrm{Ni})$ & 0.22 & 0.20 & -0.18 & 0.15 & -0.15
\end{tabular}

$$
Q(\mathrm{~A})=\sum_{k} w_{k} \sum_{\mu}^{\mathrm{A}} \sum_{v}^{\mathrm{A}} P_{\mu v}(k) S_{\mu v}(k),
$$

where $P_{\mu v}(k)$ and $S_{\mu v}(k)$ were the density and the overlap matrices respectively, $w_{k}$ was the weight associated with the calculated K-points in the Brillouin zone. Usually, the magnitude and sign of $Q(\mathrm{~A})$ characterize the A atom ionicity in the supercell, and $Q_{\mathrm{A}-\mathrm{B}}$ could be used to approximately measure the average covalent bonding strength between $\mathrm{A}$ and $\mathrm{B}$ atoms. The results are shown in Table 5.

Table 5 shows that the $\mathrm{Cu}$ element exhibits reducibility in B2-NiTi because of its losing electrons, just like the Ti element in the NiTi phase, and Fe exhibits oxidability for obtaining electrons just like the $\mathrm{Ni}$ element. Otherwise, we can see that the overlap population of $\mathrm{Ni}-\mathrm{Ti} \bar{Q}_{\mathrm{Ni}-\mathrm{Ti}}(0.21)$ in B2- NiTi $(\mathrm{Cu})$ is also less than that $\left(\bar{Q}_{\mathrm{Ni}-\mathrm{Ti}}=0.22\right)$ in B2-NiTi, namely the Ni-Ti bond strength is depressed by the $\mathrm{Cu}$ alloying process. Having scrutinized the bonding character of $\mathrm{Cu}$ and its nearest neighboring atom, it is found that $\bar{Q}_{\mathrm{Cu}-\mathrm{Ti}}$ in $\mathrm{B} 2-\mathrm{NiTi}(\mathrm{Cu} \rightarrow \mathrm{Ni})$ is 0.06 , which is smaller than $\bar{Q}_{\mathrm{Ni}-\mathrm{Ti}}$. Based on the weak bond for $Q_{\mathrm{Ni}-\mathrm{Ti}}$ and $Q_{\mathrm{Cu}-\mathrm{Ti}}$, we can see a decrease in the phase stability for NiTi $(\mathrm{Cu})$ to originate from the weakening of $\mathrm{Ni}-\mathrm{Ti}$ and $\mathrm{Cu}-\mathrm{Ti}$ bonds.

Considering the effect of Fe alloying in NiTi SMA, Table 5 elucidates the $\bar{Q}_{\mathrm{Ni}-\mathrm{Ti}}$ overlap population in B2- NiTi $(\mathrm{Fe} \rightarrow \mathrm{Ni})$ of 0.20 , which is slightly less than that in B2-NiTi $\left(\bar{Q}_{\mathrm{Ni}-\mathrm{Ti}}=0.22\right)$. $\bar{Q}_{\mathrm{Fe}-\mathrm{Ti}}(0.22)$ in $\mathrm{B} 2-\mathrm{NiTi}(\mathrm{Fe} \rightarrow \mathrm{Ni})$ is equal to $\bar{Q}_{\mathrm{Ni}-\mathrm{Ti}}(0.22)$ in B2-NiTi. Furthermore, analyzing only the Mulliken population of $\mathrm{Ni}-\mathrm{Ti}$ in $\mathrm{B} 2, \mathrm{~B} 19^{\prime}-\mathrm{NiTi}$, NiTi $(\mathrm{Cu})$, and $\mathrm{NiTi}(\mathrm{Fe})$ structures, we can see that $\bar{Q}_{\mathrm{Ni}-\mathrm{Ti}}$ is at the same level. However, $\bar{Q}_{\mathrm{Fe}-\mathrm{Ti}}$ is stronger than $\bar{Q}_{\mathrm{Cu}-\mathrm{Ti}}$, namely the structural stability of the NiTi matrix phase is strengthened by $\mathrm{Fe}$ instead of $\mathrm{Cu}$. So now we can see the bonding ability of $\mathrm{Cu}$ or $\mathrm{Fe}$ alloying elements and Ti results in the different alloying effect on $M_{\mathrm{s}}$.

Electron density difference. In order to study the chemical bonding evolution and peculiarities of the electron density, the electron density difference (EDD) of several models, such as the NiTi matrix phase, NiTi $(\mathrm{Cu})$, and NiTi $(\mathrm{Fe})$, was calculated and speculated carefully along the B2 $\rightarrow$ B19' martensitic phase tranformation direction $\{110\}\langle 110\rangle$, as shown in Fig. 3. Comparing EDD of the three models, we see that the obital grade and electron loss or gain for $\mathrm{Ni}$ and $\mathrm{Ti}$ are similar to each other, which means that the $\mathrm{Ni}-\mathrm{Ti}$ bonding is not improved by $\mathrm{Cu}$ or $\mathrm{Fe}$ alloying (labeled by (1) in Fig. 3). A detailed analysis of the bonding character of alloying element and Ti, we can see there exists an obvious difference In Fig. 3, $b$, the electron density differences between $\mathrm{Cu}-\mathrm{Ti}$ sets exhibit no visible nodes, which illuminates that there is a metallic bond between the $\mathrm{Cu}$ and $\mathrm{Ti}$ atoms just as for $\mathrm{Ni}-\mathrm{Ti}$ (labeled by (2) in Fig. 3, b). So the shear transformation ability for NiTi and NiTi $(\mathrm{Cu})$ is at the same level. After the Fe alloying process, EDD of NiTi (Fe) shows that the Fe gained electrons distinctly appear to by butterfly-like, which means that the existing strong covalent bond is the $\pi$ bond (labeled by (3) in Fig. 3,c). Furthermore, the contour lines of EDD between Fe and Ti are clear and dense, meaning the bonding strength for Fe-Ti being strong (labeled by (3) in Fig. 3, c). So the shear transformation ability for NiTiFe is improved, resulting in a decrease in $M_{\mathrm{s}}$ of $\mathrm{NiTi}(\mathrm{Fe})$ as compared to those of $\mathrm{NiTi}$ and $\mathrm{NiTi}(\mathrm{Cu})$. 


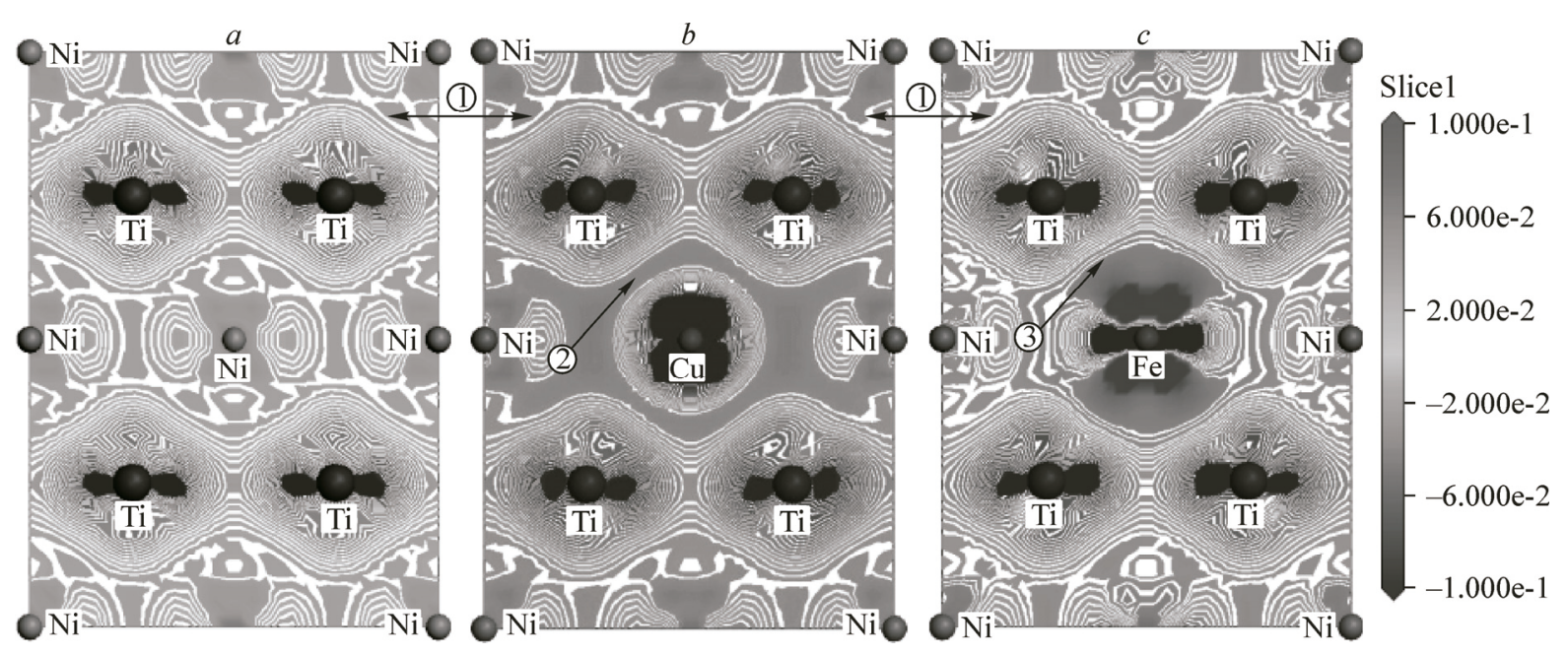

Fig. 3. Sckethc map of electronic density difference along $\{110\}\langle 110\rangle$ direction $(a) \mathrm{NiTi}(b) \mathrm{NiTi}(\mathrm{Cu} \rightarrow \mathrm{Ni})(c)$ $\mathrm{NiTi}(\mathrm{Fe} \rightarrow \mathrm{Ni})$, wherein loss of electron is labelled by button value and electron enrichment is labelled by top value as shown in Slise 1

\section{CONCLUSIONS}

The results of the calculation of the binding energy and the formation enthalpy show that the $\mathrm{Cu}$ and $\mathrm{Fe}$ elements prefer to replace the $\mathrm{Ni}$ atom in the NiTi alloy. As compared with the NiTi matrix phase, the binding energy of B2 and the $\mathrm{B} 19^{\prime} \mathrm{NiTi}(\mathrm{Cu})$ phase is nearly kept constant, albeit the binding energy of $\mathrm{NiTi}(\mathrm{Fe})$ is sharply decreased. Furthermore, the binding energy difference of $\mathrm{B} 2$ NiTi $(\mathrm{Cu})$ and $\mathrm{B} 19^{\prime}-\mathrm{NiTi}(\mathrm{Cu})$ is similar to that of B2-NiTi and B19'-NiTi, which is larger than that of B2- $\mathrm{NiTi}(\mathrm{Fe})$ and $\mathrm{B} 19^{\prime}-\mathrm{NiTi}(\mathrm{Fe})$.

The calculated shear constants $c_{44}$ and $c^{\prime}$ illuminate that the shear deformation ability of NiTi and $\mathrm{NiTi}(\mathrm{Cu})$ is at the same level, but $c_{44}$ and $c^{\prime}$ of $\mathrm{NiTi}(\mathrm{Fe})$ increase dramatically absolutely after the $\mathrm{Fe}$ alloying process. Thus, the energy barrier for the martensitic phase transformation of NiTi $(\mathrm{Fe})$ is larger than that of $\mathrm{NiTi}$ and $\mathrm{NiTi}(\mathrm{Cu})$.

The Mulliken population results indicate that $Q_{\mathrm{Cu}-\mathrm{Ti}}$ is smaller than $Q_{\mathrm{Ni}-\mathrm{Ti}}$, but $Q_{\mathrm{Fe}-\mathrm{Ti}}$ is larger than $Q_{\mathrm{Ni}-\mathrm{Ti}}$. The electron density difference shows that $\mathrm{Ni}-\mathrm{Ti}$ and $\mathrm{Cu}-\mathrm{Ti}$ have the metallic bonding, but in $\mathrm{Fe}-\mathrm{Ti}$ some covalent bonding exists.

This work was supported by the National Defense Key Discipline Laboratory Foundation of Light Alloy Processing Science and Technology (gf201301006), the Natural Science Foundation of Jiangxi Province (20132BAB216012), and the National Natural Science Foundation of China (Grant Nos. 51361026 and 50771044).

\section{REFERENCES}

1. Gelius U., Kopachev A.B., Kolpacheva O.V., Nikiforov I.Ya., Chularis A.A. // J. Struct. Chem. - 2002. - 43. - P. $932-938$.

2. Sui J.H., Gao Z.Y., Li Y.F., Zhang Z.G., Cai W. // Mater. Sci. Eng. - 2009. - A508. - P. 33 - 36.

3. Saburi T. // MRS Int. Meet. Adv. Mater. - 1989. - 9. - P. 77 - 91.

4. Xu H.B., Jiang C.B., Gong S.K. // Acta Aeronaut. Astronaut. Sin. - 2000. - 21. - P. 20 - 24.

5. Mercier O., Melton K.N. // Metal. Trans. - 1979. - A10. - P. 387 - 389.

6. Bozzolo G., Noebe R.D., Mosca H.O. // J. Alloys Compd. - 2005. - 389. - P. 80 - 94.

7. Cai W., Tan C.L., Shen T., Tian X.H. // J. Alloys Compd. - 2007. - 438. - P. 30 - 33.

8. Ye Y.Y., Chan C.T., Ho K.M. // Phys. Rev. - 1997. - B56. - P. 3678 - 3689.

9. Gong C.W., Wang Y.N., Yang D.Z. // Acta Phys. Sin. - 2006. - 55. - P. 2877 - 2881.

10. Medveva N.I., Enyashin A.N., Ivanovskii A.L. // J. Struct. Chem. - 2011. - 52 - P. 785 - 802. 
11. Vosko S.H., Wilk L., Nusair M. // Canad. J. Phys. - 1980. - 58. - P. 1200 - 1210.

12. Vanderbil T.D. // Phys. Rev. - 1990. - B41. - P. $7892-78795$.

13. Francis G.P., Payne M.C. // J. Phys.: Condens. Matter. - 1990. - 2. - P. $4395-4404$.

14. Pulay P. // Mol. Phys. - 1969. - 17. - P. $197-208$.

15. Li Z., Huang J., Meng A., Zheng B. // J. Struct. Chem. - 2010. - 51. - P. 53 - 59.

16. Mercier Q., Melton K.N., Gremaud G. // J. Appl. Phys. - 1980. - 51. - P. $1833-1837$.

17. Tan C.L., Tian X.H., Cai W. // Phys. B. (Amsterdam, Neth.). - 2009. - 404. - P. $3662-3665$.

18. Borgia C., Olliges S., Dietiker M., Pigozzi G., Splenak R. // Thin Solid Films. - 2009. - 518. - P. 1879 1885.

19. Medvedeva N.I., Gornostyev Y.N., Novikov D.L., Mryasov O.N., Freeman A.J. // Acta Mater. - 1998. - 46. - P. 3433 - 3442.

20. Brill J.I., Kim H.Y., Inamura T., Hosoda H., Miyazaki S. // Mater. Sci. Eng. - 2005. - A403. - P. 334 - 339.

21. Otsuka K., Ren X. // Prog. Mater. Sci. - 2005. -50. - P. $511-678$.

22. Planes A., Manosa L. // Solid State Phys. - 2001. - 55. - P. 159 - 267.

23. Zener C. // Phys. Rev. - 1947. - 71. - P. $846-851$.

24. Li G.F., Lu S.Q., Dong X.J., Peng P. // J. Alloys Compd. - 2012. - 542. - P. 170 - 176. 